\title{
Pinealectomy aggravates acute pancreatitis in the rat
}

\author{
Jolanta Jaworek ${ }^{1}$, Krystyna Ż wirska-Korczala², Joanna Szklarczyk ${ }^{1}$, \\ Katarzyna Nawrot-Porąbka ${ }^{1}$, Anna Leja-Szpak ${ }^{1}$, Andrzej K. Jaworek ${ }^{3}$, \\ Romana Tomaszewska ${ }^{4}$ \\ ${ }^{1}$ Department of Medical Physiology, Faculty of Health Sciences, Jagiellonian University, Medical College, \\ Michałowskiego 12, PL 31-126 Kraków, Poland \\ ${ }^{2}$ University of Silesia, Traugutta 2, PL 41-800, Zabrze, Poland; \\ ${ }^{3}$ Chair of Dermatology, Medical Faculty, Jagiellonian University, Medical College, Skawińska 8, PL 31-121 Kraków, \\ Poland \\ ${ }^{4}$ Cell Morphology, Medical Faculty, Jagiellonian University, Medical College, Grzegórzecka 16, PL 31-531 Kraków, \\ Poland
}

Correspondence: Jolanta Jaworek, e-mail: mpjawore@cyf-kr.edu.pl

\begin{abstract}
:
Melatonin, a pineal indoleamine, protects the pancreas against acute damage; however, the involvement of the pineal gland in the pancreatoprotective action of melatonin is unknown. The primary aim of this study was to determine the effects of pinealectomy on the course of acute caerulein-induced pancreatitis (AP) in rats. AP was induced by a subcutaneous infusion of caerulein $(25 \mu \mathrm{g} / \mathrm{kg})$ into pinealectomized or sham-operated animals. Melatonin ( 5 or $25 \mathrm{mg} / \mathrm{kg}$ ) was given via intraperitoneal (ip) injection 30 min prior to the induction of AP. The pancreatic content of the lipid peroxidation products malondialdehyde and 4-hydroxynonenal (MDA + $4 \mathrm{HNE}$ ) and the activity of an antioxidative enzyme, glutathione peroxidase (GSH-Px), were measured in each group of rats. Melatonin blood levels were measured by radioimmunoassay (RIA). In the sham-operated rats, AP was confirmed with histological examination and manifested as pancreatic edema and an increase in the blood lipase level (by 1,500\%). In addition, the pancreatic content of MDA $+4 \mathrm{HNE}$ was increased by $200 \%$, and pancreatic glutathione peroxydase (GSH-Px) activity was reduced by $40 \%$. Pinealectomy significantly aggravated the histological manifestations of AP, reduced the GSH-Px activity and markedly augmented the levels of MDA $+4 \mathrm{HNE}$ in the pancreas of rats with or without AP as compared to sham-operated animals. Melatonin was undetectable in the blood of the pinealectomized rats with or without AP. Treatment with melatonin $(25 \mathrm{mg} / \mathrm{kg}$, ip $)$ prevented the development of AP in the sham-operated rats and significantly reduced pancreatic inflammation in the animals previously subjected to pinealectomy. In conclusion, pineal melatonin contributes to the pancreatic protection through the activation of the antioxidative defense mechanism in pancreatic tissue as well as its direct antioxidant effects.
\end{abstract}

\section{Key words:}

melatonin, pinealectomy, acute pancreatitis, GSH-Px, pancreatoprotection 


\section{Introduction}

Melatonin, in addition to being produced in the pineal gland, is also present in the gastrointestinal tract. The total amount of melatonin in the gut is 400 times greater than that in the pineal gland $[4,8,17,54]$. Enteroendocrine (EE) cells have been shown to be a source of melatonin in the gut [36].

Melatonin is best known as a beneficial substance that effectively protects various tissues against the toxic effects of reactive oxygen (ROS) and nitrogen (RNS) species [33, 37, 47]. Under normal conditions, these free radicals are generated by mitochondrial metabolism and immediately neutralized by enzymatic and non-enzymatic natural scavengers [38]. During inflammation, the normal antioxidative system is inadequate due to the accelerated production of free radicals [25]. Melatonin acts as a non-enzymatic scavenger [33, 37, 47] and as an activator of antioxidative enzymes, including superoxide dismutase (SOD) and glutathione peroxidase (GSH-Px) [3, 16, 25, 38, 41]. In addition, melatonin stabilizes lipid membranes, protects the membranes from peroxidation and modulates the immune response of the organism $[9,27,31$, 45]. Melatonin also improves the healing processes because it accelerates angiogenesis, increases the formation of new blood vessels and stimulates vascular endothelial growth factor (VEGF) expression, thus improving the quality of wound healing and scar formation [35].

Melatonin exerts most of its widespread effects though cellular membrane receptors and nuclear/binding sites; however, some of melatonin's actions are receptor-independent. There are no morphological barriers to melatonin, and due to its high lipophilicity, it easily penetrates into cells [40].

As shown in previous studies, exogenous melatonin, as well as its precursor, L-tryptophan, significantly attenuates the acute pancreatitis induced by caerulein over-stimulation or ischemia/reperfusion $[19,22,50]$. Subsequently, it has been found that luzindole, an antagonist of melatonin MT2 receptors, aggravates acute pancreatitis $[20,26]$. These observations suggest that endogenous melatonin may play a role in the physiological defense of the pancreas and could attenuate the intensity of the inflammatory processes in this gland. However, it is not known if melatonin released from the pineal gland normally participates in the protection against acute pancreatitis.
Because the role of the pineal gland in pancreatic defense has not been investigated to date, we assessed the effect of pinealectomy on the course of acute pancreatitis. In this study, we compared the severity of acute caerulein-induced pancreatitis (AP) in rats subjected to a pinealectomy with that of animals with an intact pineal gland.

\section{Materials and Methods}

\section{Animals and drugs}

The following items were used in these experiments: caerulein and melatonin from Sigma Co. (St. Louis, MO, USA), a rat melatonin radioimmunoassay (RIA) kit from IBL Immuno-Biological Laboratories (Hamburg, Germany), lipa DT slides from Vitros DT System, Johnson and Johnson Clinical Diagnostic, Inc. (Rochester NY, USA), an LPO-586 commercial kit for the determination of malondialdehyde and 4-hydroxynonenal (MDA + 4HNE) and a GSH-Px commercial kit from OXIS Research (Portland, OR, USA); vetbutal was from Biowet (Puławy, Poland).

Studies were performed on male Wistar rats weighing 150-200 g. Animals were housed in cages under standard conditions at room temperature on a $12 \mathrm{~h}$ light : $12 \mathrm{~h}$ dark cycle with commercial pellet chow. Rats were deprived of food $17 \mathrm{~h}$ prior to the start of the experiment, but drinking water was available $a d$ libitum. The experimental protocol was approved by the Jagiellonian University Ethical Committee for Animal Experimentation.

Pinealectomy was performed according to the method of Kato et al. [23]. Briefly, rats were anesthetized with vetbutal $(0.0025 \mathrm{ml} / \mathrm{g}$ body weight). An incision was made in the sagittal region of the head, and the bones were drilled with a dental bur to allow visualization of the transverse and sagittal sinuses. The pineal gland was removed by aspiration through the sagittal sinus via a special needle. In the shamoperated animals, the needle was inserted and withdrawn without the application of suction. At the end of the surgery, a histological examination of each pineal gland was carried out to verify the completeness of pinealectomy and the absence of damage to nearby brain areas. 


\section{Experimental protocol}

Experiments with acute pancreatitis started 4 weeks after the pinealectomy. All experiments were carried out in the morning. During the experiments, the rats were placed in individual Bollman cages. Acute pancreatitis was induced with a subcutaneous $(s c)$ infusion of caerulein $(5 \mu \mathrm{g} / \mathrm{kg}-\mathrm{h}$ for $5 \mathrm{~h})$. Caerulein was diluted in saline and infused at a rate $1 \mathrm{ml} / \mathrm{h}$. Control groups received $0.5 \mathrm{ml}$ of vehicle saline injected $i p$, followed $30 \mathrm{~min}$ later by an $s c$ infusion of $0.9 \%$ saline for $5 \mathrm{~h}$. Melatonin ( 5 or $25 \mathrm{mg} / \mathrm{kg}$ ) was dissolved in absolute ethanol and then diluted in physiological saline to the appropriate concentrations and given at a volume of $0.5 \mathrm{ml}$ to the rats as a bolus ip injection $30 \mathrm{~min}$ prior to the start of caerulein administration. In control rats, $0.5 \mathrm{ml}$ of saline was administered instead of the test substances (Fig. 1).

This study included two parts. Part A was carried out in rats with an intact pineal gland (sham-operated), whereas part B included pinealectomized animals (Fig. 1). The following study groups were used in both parts (A and $\mathrm{B}$ ) of the study: 1) control animals that received $0.5 \mathrm{ml}$ of vehicle ip followed by an $s c$ infusion of $0.9 \%$ saline for $5 \mathrm{~h} ; 2$ ) acute pancreatitis rats that were given an $s c$ infusion of caerulein; 3) acute pancreatitis + melatonin rats that were given melatonin $30 \mathrm{~min}$ before the caerulein administration, 4) melatonin-treated rats that were given melatonin followed by an $s c$ infusion of $0.9 \%$ saline for $5 \mathrm{~h}$.

\section{Determination of plasma levels of lipase and melatonin}

At the end of the experiments, the animals were anesthetized with vetbutal and weighed. The abdominal cavity was then opened, and the vena cava was exposed. Blood was drawn to determine lipase activity and melatonin concentration. The blood was kept at room temperature for $2 \mathrm{~h}$ without anticoagulants and then centrifuged. The collected serum samples were stored at $-80^{\circ} \mathrm{C}$. Serum lipase was measured with a Kodak Ektachem DT System analyzer (Eastman Kodak Company, Rochester NY, USA) using Lipa DT commercial slides, as described elsewhere [22]. The concentration of plasma melatonin was measured with RIA using rat melatonin according to the manufacturer's procedure as described previously $[19,20]$.

\section{Pancreatic weight and histological examination}

The pancreas was carefully removed by severing the attachments to the stomach, duodenum and spleen. After the pancreas was rinsed and weighed, pieces of it were excised from the body portion, fixed in $10 \%$ formalin and stained with hematoxylin and eosin. The pancreatic samples were examined by a professional histologist who was unaware of the treatment given. A histological grading of edema, leukocyte infiltration and vacuolization were made using a scale ranging from 0 to 3, as described previously [20, 22].

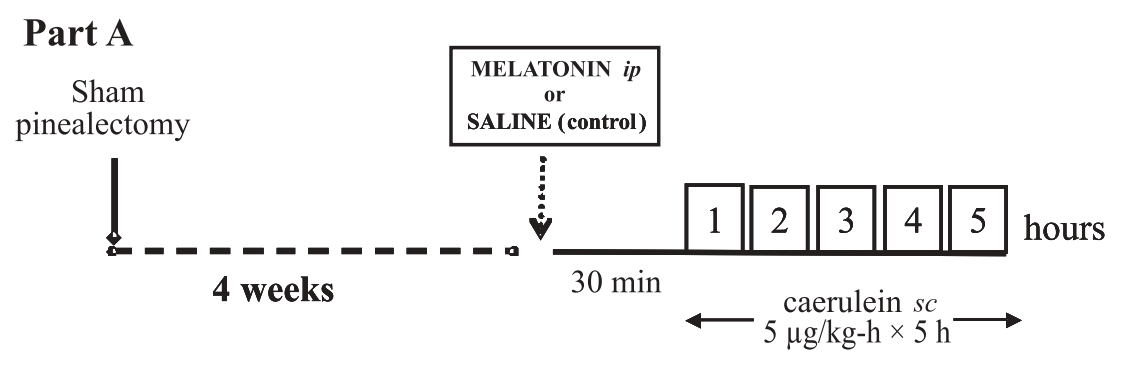

Fig. 1. Experimental protocol

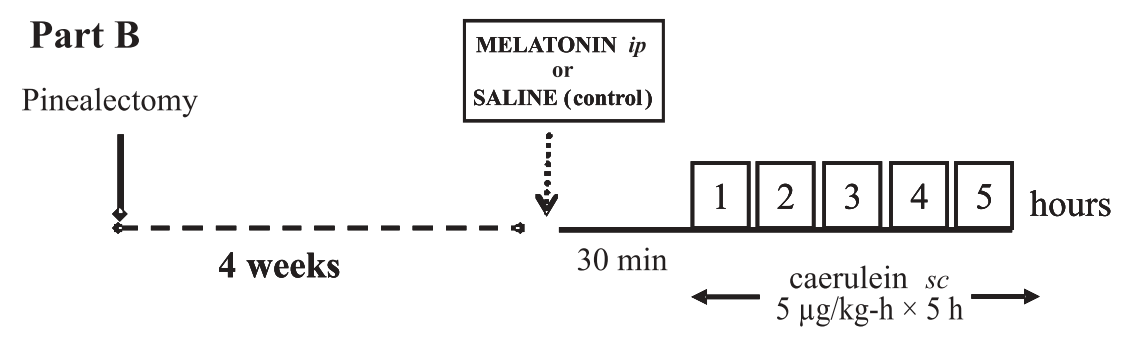

Melatonin: 5 or $25 \mathrm{mg} / \mathrm{kg}$ 


\section{Determination of MDA + 4HNE and GSH-Px activity in the pancreatic tissue}

Samples of fresh pancreatic tissue were taken to determine the level of the lipid peroxidation products, $\mathrm{MDA}+4 \mathrm{HNE}$, using the LPO-586 commercial kit, according to the manufacturer's protocol. Briefly, $300 \mathrm{mg}$ samples of pancreatic tissue were homogenized in a phosphate buffer $(20 \mathrm{mmol} / \mathrm{l}, \mathrm{pH} 7.4)$ using a homogenizer Ultra-Turrax T25 from Janke \& Kunkel IKA - Labortechnik (sample volume $0.5 \mathrm{ml}$, temp $4^{\circ} \mathrm{C}, 2,400 \mathrm{rev} / \mathrm{min}$ for $15 \mathrm{~s}$ ). Then, $10 \mu \mathrm{l}$ of $0.5 \mathrm{M}$ butylated hydroxytoluene in acetonitrile was added to each sample to prevent tissue oxidation. Samples were centrifuged, and the pellets were immediately frozen at $-70^{\circ} \mathrm{C}$ until assay. MDA $+4 \mathrm{HNE}$ was measured in duplicate and expressed as $\mathrm{nmol} / \mathrm{g}$ of tissue.

To determine the activity of GSH-Px, samples of pancreatic tissue were perfused with $0.9 \% \mathrm{NaCl}$, followed by homogenization and centrifugation, as described above. The colorimetric assay was used to assess the GSH-Px activity. This activity was measured in duplicate and expressed as $\mu \mathrm{mol} / \mathrm{g}$ of pancreatic tissue.

\section{Statistical analysis}

The differences between the mean values of various groups of experiments were compared using an ANOVA and Student's $t$-test for unpaired data. The MannWhitney non-parametric U test was used for unpaired variables. A difference with a $p$ value of $<0.05$ was considered statistically significant. Results are expressed as the means \pm SEM.

\section{Results}

In the control rats with an intact pineal gland, the mean pancreatic weight was $880 \pm 70 \mathrm{mg}$, and the serum lipase level was $84 \pm 10 \mathrm{IU} / 1$. Pinealectomy alone had no significant effect on pancreatic weight, pancreatic morphology or the serum lipase concentration (Tab. 1, Figs. 2 and 3).

The subcutaneous infusion of caerulein produced AP in all animals tested. In the rats with an intact pineal gland, administration of the caerulein led to a significant increase in pancreatic weight $(1,780 \pm 150 \mathrm{mg})$ and serum lipase level $(10,072 \pm 2,380 \mathrm{IU} / 1$; Figs. 2 and 3 ). In the AP rats, typical pancreatic lesions were observed, and the pancreas was enlarged. Peritoneal fluid was present in all animals. Edema was accompanied by the perivascular infiltration of leukocytes and the vacuolization of the acinar cells (Tab. 1).

Pinealectomy resulted in a significant aggravation of AP, which manifested as a marked increase in the pancreatic weight $(2,220 \pm 150 \mathrm{mg})$ and plasma lipase concentration $(15,900 \pm 1,140 \mathrm{IU} / 1)$. These values were significantly higher than the values observed in rats with an intact pineal gland (Figs. 2 and 3). In addition, the histological manifestations of AP, including edema and infiltration of pancreatic tissue with leukocytes, were significantly more extensive in the AP rats with a pinealectomy (Tab. 1).

As expected, the pretreatment of AP rats with melatonin significantly and dose-dependently reversed the harmful effects of AP on pancreatic weight, pancreatic morphology and serum lipase concentration in both groups of rats (Tab. 1, Figs. 1 and 2). Histologi-

Tab. 1. Effect of melatonin pretreatment on pancreatic morphology in AP rats with or without pineal gland. Asterisk $\left({ }^{\star}\right)$ indicates significant $(p<$ 0.05 ) increase above the value obtained in AP rats with intact pineal gland

\begin{tabular}{|c|c|c|c|c|}
\hline & & Edema & Neutrophil infiltration & Vacuolization \\
\hline & Control intact & $0.2 \pm 0.4$ & $0.0 \pm 0.0$ & $0.0 \pm 0.0$ \\
\hline & Control pinealectomy & $0.2 \pm 0.4$ & $0.0 \pm 0.0$ & $0.0 \pm 0.0$ \\
\hline \multirow{3}{*}{ Intact pineal gand } & $\mathrm{AP}$ & $2.3 \pm 0.0$ & $2.1 \pm 0.0$ & $2.5 \pm 0.2$ \\
\hline & Melatonin $5 \mathrm{mg} / \mathrm{kg}$, ip + AP & $2.0 \pm 0.2$ & $2.0 \pm 0.2$ & $2.0 \pm 0.0$ \\
\hline & Melatonin $25 \mathrm{mg} / \mathrm{kg}$, ip + AP & $0.6 \pm 0.2$ & $1.3 \pm 0.4$ & $1.1 \pm 0.3$ \\
\hline \multirow{3}{*}{ Pinealectomy } & $\mathrm{AP}$ & $2.8 \pm 0.2^{*}$ & $2.5 \pm 0.0^{\star}$ & $3.0 \pm 0.3^{\star}$ \\
\hline & Melatonin $5 \mathrm{mg} / \mathrm{kg}$, ip + AP & $2.1 \pm 0.5$ & $2.2 \pm 0.4$ & $2.2 \pm 0.4$ \\
\hline & Melatonin $25 \mathrm{mg} / \mathrm{kg}$, ip + AP & $0.8 \pm 0.4$ & $1.0 \pm 0.2$ & $1.0 \pm 0.3$ \\
\hline
\end{tabular}



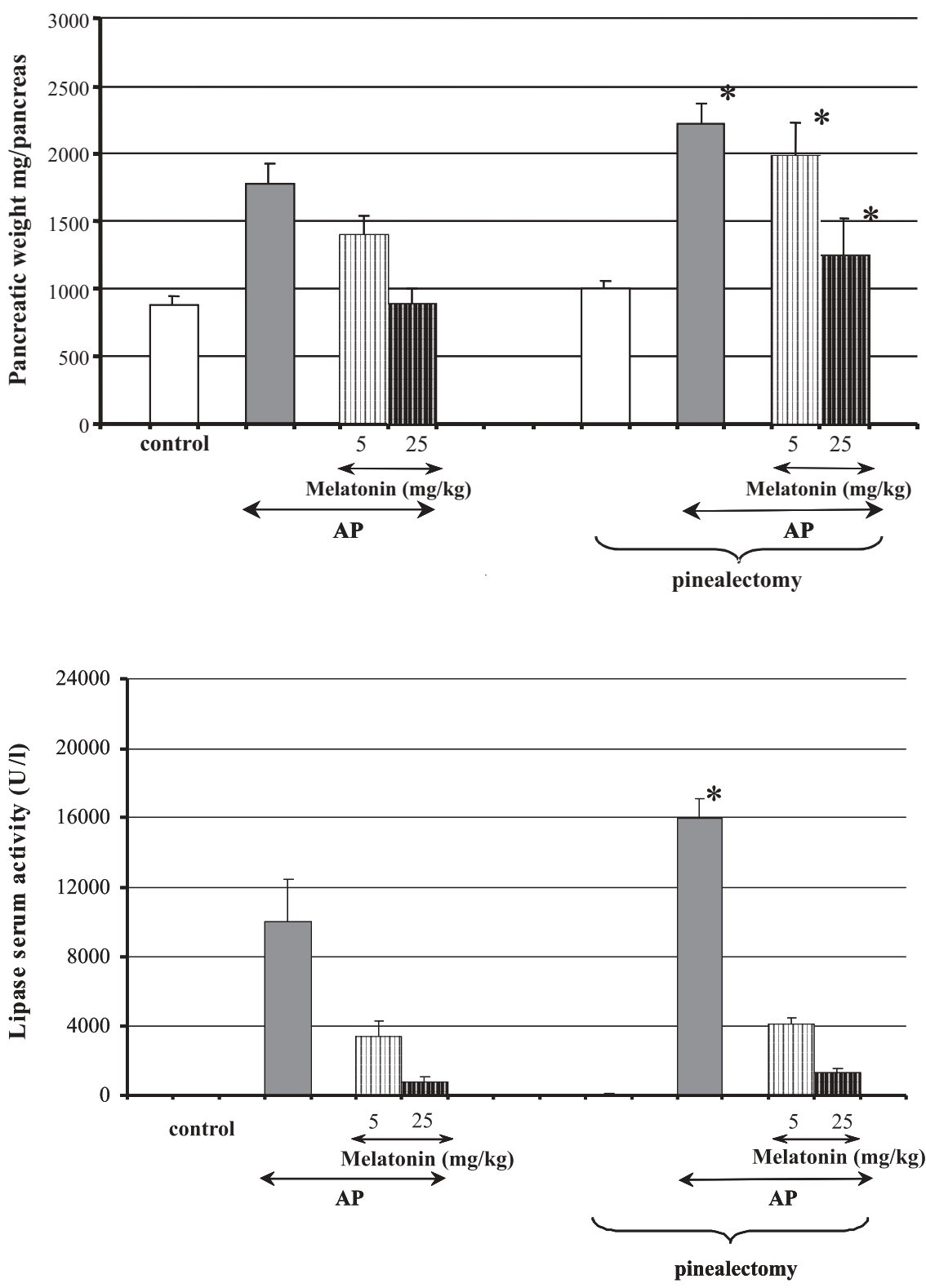

Fig. 2. Effect of pinealectomy on pancreatic weight in rats subjected to caerulein-induced pancreatitis (AP) with or without pretreatment with melatonin. Control = intact animals. The bars represent the means \pm SEM from the separate experiments, each performed on 8-10 rats. The asterisks indicate significant $(p<0.05)$ increases above the values detected in control animals

Fig. 3. Effect of pinealectomy on lipase serum activity in rats subjected to caerulein-induced pancreatitis (AP) with or without pretreatment with melatonin. Control $=$ intact animals. The bars represent the means \pm SEM from the separate experiments, each performed on 8-10 rats. The asterisk indicates a significant $(p<0.01)$ increase above the values detected in control animals cal assessment showed a beneficial effect of melatonin pretreatment in pancreatic tissue from both sham-operated and pinealectomized rats (Tab. 1).

The melatonin concentration from the serum was $77 \pm 11 \mathrm{pg} / \mathrm{ml}$ in the sham-operated animals. In the rats with AP, the serum melatonin level was significantly increased $(204 \pm 50 \mathrm{pg} / \mathrm{ml})$, compared to the control animals (Fig. 4). Pinealectomy alone resulted in a dramatic reduction of indoleamine immunoreactivity in both groups of animals with or without the induction of AP (Fig. 3). Treatment with melatonin produced a dose-dependent increase in serum indoleamine levels (Tab. 2, Fig. 4).
Tab. 2. Effect of melatonin pretreatment ( 5 or $25 \mathrm{mg} / \mathrm{kg}$, ip) on serum melatonin concentration $(\mathrm{pg} / \mathrm{ml})$ in the rats with intact or removed pineal gland, without acute pancreatitis. Asterisk $\left({ }^{*}\right)$ indicates significant $(p<0.05)$ increase above the value obtained in control rats with intact pineal gland

\begin{tabular}{ccc}
\hline & $\begin{array}{c}\text { Rats with intact } \\
\text { pineal gland }\end{array}$ & $\begin{array}{c}\text { Rats with removed } \\
\text { pineal gland }\end{array}$ \\
\hline Control & $77 \pm 11$ & $1.7 \pm 0.1$ \\
$\begin{array}{c}\text { Melatonin } \\
5 \mathrm{mg} / \mathrm{kg}, \text { ip }\end{array}$ & $490 \pm 100^{*}$ & $570 \pm 80^{*}$ \\
$\begin{array}{c}\text { Melatonin } \\
25 \mathrm{mg} / \mathrm{kg}, \text { ip }\end{array}$ & $1280 \pm 80^{*}$ & $1350 \pm 220^{*}$ \\
\hline
\end{tabular}


Fig. 4. Effect of pinealectomy on serum melatonin concentration in rats subjected to caerulein-induced pancreatitis (AP) with or without pretreatment with melatonin. Melatonin was given to the rats as a bolus ip injection, and blood samples were collected $5.5 \mathrm{~h}$ later for the determination of melatonin serum levels. Control $=$ intact animals The bars represent the means \pm SEM from the separate experiments, each performed on $8-10$ rats. The asterisks indicate significant $(p<0.05)$ increases above the control value
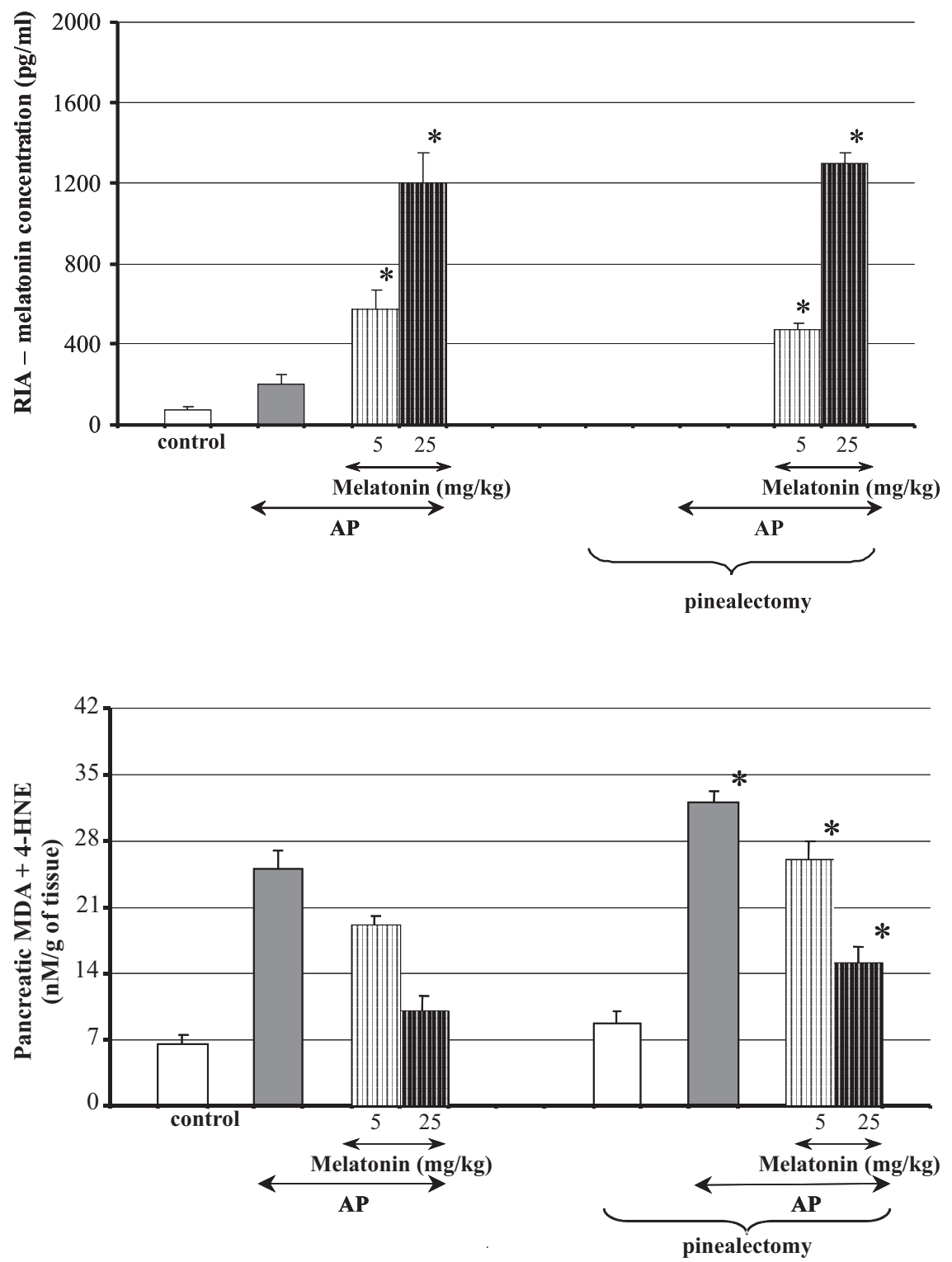

Fig. 5. Pancreatic $M D A+4 H N E$ in $A P$ rats subjected to pinealectomy and in AP rats with intact pineal glands, with or without pretreatment with melatonin Control = intact animals. The bars represent the means \pm SEM from the separate experiments, each performed on $8-10$ rats. The asterisks indicate significant $(p<0.05)$ increases above the values detected in control animals

Under normal conditions, MDA + 4HNE levels were low in the pancreatic tissue $(6.5 \pm 1.0 \mathrm{nM} / \mathrm{g}$ of tissue), and pinealectomy alone did not alter these levels $(8.7 \pm 1.3 \mathrm{nM} / \mathrm{g}$ of tissue; Fig. 5$)$. The induction of AP resulted in the marked increase of these lipid peroxidation products in the pancreases of both intact $(25.0 \pm 1.0 \mathrm{nM} / \mathrm{g}$ of tissue $)$ and pinealectomized rats $(32.1 \pm 1.2 \mathrm{nM} / \mathrm{g}$ of tissue). However, in the pinealectomized animals, the increase in MDA $+4 \mathrm{HNE}$ levels was significantly higher than in animals with an intact pineal gland (Fig. 5). Following the administration of higher doses of melatonin in AP rats, the pancreatic content of MDA $+4 \mathrm{HNE}$ was normalized in the animals with an intact pineal gland $(10.0 \pm 1.5 \mathrm{nM} / \mathrm{g}$ of tissue), and it was strongly reduced in the pinealectomized animals (15. $1 \pm 1.8 \mathrm{nM} / \mathrm{g}$ of tissue; Fig. 5).

In the intact rats, the pancreatic activity of GSH-Px was $27.5 \pm 2.0 \mu \mathrm{M} / \mathrm{g}$ of tissue. This activity was reduced in pinealectomized animals to $19.5 \pm 2.0 \mu \mathrm{M} / \mathrm{g}$ of tissue (Fig. 6). The induction of AP led to a marked drop in the GSH-Px activity in the pancreases of both intact $(15.2 \pm 3.5 \mu \mathrm{M} / \mathrm{g})$ and pinealectomized rats $(11.3 \pm 2.0 \mu \mathrm{M} / \mathrm{g}$ of tissue). The administration of melatonin prior to the onset of AP led to a dosedependent enhancement of GSH-Px activity. Pretreatment with higher doses of melatonin in AP rats significantly elevated the GSH-Px activity in the pancreas of animals with intact pineal glands $(25.0 \pm 4.0 \mu \mathrm{M} / \mathrm{g}$ 


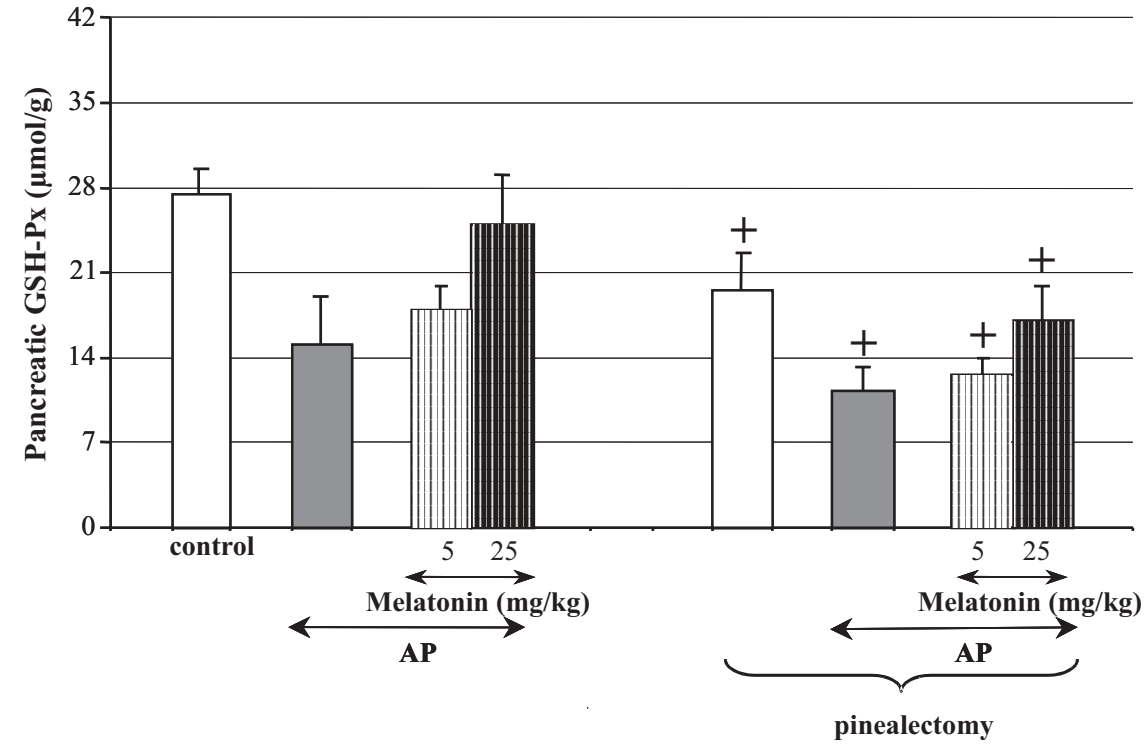

Fig. 6. Pancreatic GSH-Px in the AP rats subjected to pinealectomy and in the AP rats with intact pineal glands, with or without pretreatment with melatonin. Control = intact animals. The bars represent the means \pm SEM from the separate experiments, each performed on 8-10 rats. Crosses indicate significant $(p<0.05)$ decreases below the values detected in control animals of tissue) and in the pinealectomized animals (17.3 \pm $3.0 \mu \mathrm{M} / \mathrm{g}$ of tissue; Fig. 6).

\section{Discussion}

The results of the present study show, for the first time, that removal of the pineal gland results in a significant aggravation of acute caerulein-induced pancreatitis in rats. The injection of exogenous melatonin reversed the harmful effects of pinealectomy in rats subjected to acute inflammation.

In addition to the pineal gland, melatonin is produced in the gastrointestinal tract and released, under some circumstances, into circulation [8, 17]. The physiological role of the melatonin produced in the gut remains unclear. In the gastrointestinal system, melatonin relaxes the smooth muscles of the gut and blood vessels and increases mucosal blood flow, thus preventing the development or initiating the healing of gastric and intestinal ulcers $[6,23,49,51,52]$. It is also an effective agent against experimental colitis [48].

In the pancreas, melatonin has been shown to modulate pancreatic enzyme secretion and to attenuate AP in various experimental models $[10,11,18-20$, 22, 30, 46, 50]. Melatonin exerts its beneficial effects through several mechanisms, including scavenging free radicals, activating antioxidative enzymes, inhibiting neutrophil infiltration, promoting neutrophil apoptosis, modulating cytokine production and alter- ing the generation of pancreatic prostaglandins [10, $11,18,22,30,46,50]$. In addition, the melatonin precursor, L-tryptophan, increases the level of melatonin in the blood and attenuates AP in rats $[22,26,50]$. In agreement with the above observations, the administration of luzindole, an MT2 melatonin receptor antagonist, aggravates AP, indicating that the effect of melatonin in curtailing the inflammatory response may involve an action of melatonin on receptors [20]. Both melatonin receptor subtypes MT1 (through the reduction of cAMP) and MT2 (through the cGMP signalling pathway) contribute to the insulin-inhibiting effect of melatonin [43, 44].

Although the gastrointestinal tract is the largest source of melatonin in the organisms, pineal melatonin has been implicated in physiological development and defense against many gastrointestinal tissues [5]. Removal of the pineal gland results in diminished glucose tolerance and insulin resistance [34]. Pinealectomy also leads to oxidative and structural damage in the liver. All of the above changes are diminished by melatonin treatment [42].

Life-long observations of rats subjected to pinealectomy revealed that the deficiency of melatonin leads to an increased generation of free radicals in tissues and an accelerated accumulation of oxidatively damaged products in the liver, kidney and pancreas [39, 42]. In pinealectomized animals, degenerative changes have also been observed in the heart and the central nervous system $[13,24,28]$. Removal of the pineal gland and the subsequent reduction of pineal melatonin make the organism more vulnerable to trauma, 
aggravate ischemic damage in the brain and spinal cord and facilitate epileptogenic processes [1, 14]. In rats subjected to pinealectomy, a significant increase in lipid peroxidation products and a marked reduction of the antioxidative enzymes have been shown $[1,2,12$, $14,15,24,32]$. These changes are invariably reversed by melatonin substitution [13, 14, 24, 28].

The current findings reinforce the observations concerning the increased susceptibility of pinealectomized animals to inflammatory tissue damage. In this study, we demonstrated that rats deprived of pineal melatonin exhibited an aggravation of AP, as indicated by the marked increase in serum lipase activity and the significantly higher accumulation of lipid peroxidation products in the pancreatic tissue compared to animals with intact pineal glands. Additionally, the activity of the antioxidative enzyme GSH-Px, which is considered to be an indicator of AP severity [53], was significantly reduced in the tissue of pinealectomized rats. These observations are consistent with reports showing that pinealectomy leads to a reduction in GSH-Px in the serum, central nervous system and renal tissue $[1,12,29]$.

A major finding of this study is that pineal melatonin is implicated in protecting the pancreatic tissue from acute inflammation. Melatonin is released from the pineal gland at night, whereas gastrointestinal melatonin production is dependent on food intake [3, 4, 7]. Given that melatonin levels in the blood are higher at night than during the day, it appears that the nocturnally elevated levels of melatonin are sufficient to modulate the inflammatory process in the pancreas [21].

In conclusion, the results of this study show that pinealectomy aggravates AP, and this effect is related to the dramatic reduction in melatonin levels and low antioxidative enzyme concentrations in the pancreatic tissue of the pinealectomized animals. This observation supports the hypothesis that pineal melatonin plays a role in the physiological protection of the pancreas against damage by acute inflammation.

\section{References:}

1. Ates O, Cayli S, Gurses I, Yucel N, Altinoz E, Iraz M, Kocak A, Yologlu S: Does pinealectomy affects the recovery rate after spinal cord injury? Neurol Res, 2007, 29, 533-539.

2. Baydas G, Gursu MF, Yilmaz S, Canpolat S, Yasar A, Cikim G, Canatan H: Daily rhythm of glutatione peroxydase activity, lipid peroxidation and glutathione levels in tissue of pinealectomized rats. Neurosci Lett, 2002, 323, 195-198.

3. Berra B, Rizzo AM: Melatonin: circadian rhythm regulator, chronobiotic, antioxidant and beyond. Clin Dermatol, 2009, 27, 202-209.

4. Bubenik GA: Gastrointestinal melatonin: localization, function and clinical relevance. Dig Dis Sci, 2002, 47, 2336-2348.

5. Bubenik GA: Localization of melatonin in the digestive tract of the rat. Effect of maturation, diurnal variation, melatonin treatment and pinealectomy. Horm Res, 1980, 12, 313-323.

6. Bubenik GA, Ayles HL, Frindship RM, Brown GM, Ball RO: Relationship between melatonin levels in plasma and gastrointestinal tissues and the incidence and severity of gastric ulcers in pigs. J Pineal Res, 1995, 24, 62-66.

7. Bubenik GA, Brown GM: Pinealectomy reduces melatonin levels in the serum but not in the gastrointestinal tract of the rat. Biol Sign, 1997, 6, 40-44.

8. Bubenik GA, Brown GM, Grota LJ: Immunohistological localization of melatonin in the rat digestive tract. Experientia, 1977, 33, 662-663.

9. Carillo-Vico A, Reiter RJ, Lardone PJ, Herrera IL, Fernandez-Monstesinos R, Guerrero JM, Pozo D: The modulatory role of melatonin on immune responsiveness. Curr Opin Investig Drugs, 2006, 7, 423-431.

10. Chen HM, Chen JC, Ng CJ, Chiu DF, Chen MF: Melatonion reduces pancreatic prostaglandins production and protects against caerulein-induced pancreatitis in rats. J Pineal Res, 2006, 40, 34-39.

11. Chen HM, Hsu JT, Chen JC, Ng CJ, Chiu DF, Chen MF: Delayed neutrophil apoptosis attenuated by melatonin in human acute pancreatitis. Pancreas, 2005, 31, 3560-364.

12. Dabrowska K, Stuss M, Gromadzinska J, Wasowicz W, Sewerynek E: The effects of melatonin on glutatione peroxydase activity in serum and erythocytes after adriamycin in normal an pinealectomized rats. Endocrinol Pol, 2008, 59, 200-206.

13. De Butte M, Pappas BA. Pinealectomy causes hippocampal CA1 and CA3 cell loss; reversal by melatonin supplementation. Neurobiol Aging, 2007, 28, 306-313.

14. De Lima E, Soares JM, del Carmen Sanabria Garrido Y, Gomez Valente S, Priel MR, Chada Baracat R, Abrăo Cavalheiro E et al.: Effect of pinealectomy and the treatment with melatonin on the temporal lobe epilepsy in rat. Brain Res, 2005, 1043, 24-31.

15. Esrefoglu M., Seyhan M, Gul M, Parlakpinar H, Batcioglu K, Uyumlu B: Potent therapeutic effect of melatonin on aging skin in pinealectomized rats. J Pineal Res, 2005, 39, 231-237.

16. Gunasingh MJ, Philip JE, Ashok BS, Kirubagaran R, Jebaraj WC, Davis GD, Vignesh S et al.: Melatonin prevents amyloid protofibrillar induced oxidative imbalance and biogenic amine catabolism. Life Sci, 2008, 83, 96-102.

17. Huether G, Poeggler B, Reimer A, George A: Effects of tryptophan administration on circulating melatonin levels in chicks and rats: evidence for stimulation of melatonin synthesis and release in the gastrointestinal tract. Life Sci, 1992, 51, 945-953. 
18. Jaworek J: Ghrelin and melatonin in the regulation of pancreatic exocrine secretion and maintaining of integrity. J Physiol Pharmacol, 2006, 57, 83-96.

19. Jaworek J, Brzozowski T, Konturek SJ: Melatonin as an organoprotector in the stomach and in the pancreas. J Pineal Res, 2005, 38, 73-83.

20. Jaworek J, Konturek SJ, Leja-Szpak A, Nawrot K, Bonior J, Tomaszewska R, Stachura J, Pawlik WW: Role of endogenous melatonin and its $\mathrm{MT}_{2}$ receptor in the modulation of caerulein-induced pancreatitis in the rat. J Physiol Pharmacol, 2002, 53, 791-804.

21. Jaworek J, Konturek SJ, Tomaszewska R, Leja-Szpak A, Bonior J, Nawrot K, Palonek M et al.: The circadian rhythm of melatonin modulates the severity of caerulein- induced pancreatitis in the rat. J Pineal Res, 2004, 37, 161-170.

22. Jaworek J, Leja-Szpak A, Bonior J, Nawrot K, Tomaszewska R, Stachura J, Sendur R et al.: Protective effect of melatonin and its precursor L-tryptophan on acute pancreatitis induced by caerulein overstimulation or ischemia/reperfusion. J Pineal Res, 2003, 34, 40-52.

23. Kato K, Murai I, Asai S, Matsuno Y, Komuro S, Kaneda N, Iwasaki A et al.: Protective role of melatonin and the pineal gland in modulating water immersion restraint stress ulcer in the rats. J Clin Gastroenterol, 1998, 27, Suppl 1, S110-S115.

24. Kilic E, Ozdemir YG, Bolay Y, Kelestimur H, Dalkara T: Pinealectomy aggravates and melatonin administration attenuates brain damage in focal ischemia. J Cereb Blood Flow Metab, 1999, 19, 511-516.

25. Korkmaz A, Reiter RJ, Topal T, Manchester LC, Oter S, Tan DX: Melatonin: an established antioxidant worthy of use in clinical trials. Mol Med, 2009, 15, 43-50.

26. Leja-Szpak A. Jaworek J, Tomaszewska R, Nawrot K, Bonior J, Kot M, Palonek M et al.: Melatonin precursor; L-tryptophan protects the pancreas from development of acute pancreatitis though the central site of action. J Physiol Pharmacol, 2004, 55, 239-254.

27. Miller SC, Pandi-Perumal SR, Esquifino AI, Cardinali DP, Maestroni GJ: The role of melatonin in immunoenhancement: potential application in cancer. Int Exp Pathol, 2006, 87, 81-87.

28. Mizrak B, Parlakpinar H, Acet A, Turkoz Y: Effect of pinealectomy and exogenous melatonin on rat hearts. Acta Histochem, 2004, 106, 29-36.

29. Mogulkoc R, Baltaci AK, Aydin L, Oztekin E, Tuncer I: Pinealectomy increases oxidant damage in kidney and testis caused by hyperthyroidism in rats. Cell Biochem Funct, 2006, 24, 449-453.

30. Muńoz-Casarez FC, Padillo FJ, Briceńo J, Collado JA, Muńoz-Castañeda JR, Ortega R, Cruz A et al.: Melatonin reduced apoptosis and necrosis induced by ischemia/reperfusion injury of the pancreas. J Pineal Res, 2006, 40, 195-203.

31. Ortega-Gutiérrez S, Fuentes-Broto L, Garcia JJ, LópezVincente M, Martinez-Ballarin E, Miana-Mena MJ, Millán-Plano S, Reiter RJ: Melatonin reduced protein and lipid oxidative damage induced by homocysteine in rat brain homogenates. J Clin Biochem, 2007, 102, 729-735.

32. Oztekin E, Baltaci AK, Tiftik AM, Mogulkoc R: Lipid peroxidation in ovariectomized and pinealectomized rats: the effects of estradiol and progesterone supplementation. Cell Biochem Funct, 2007, 25, 551-554.

33. Peyrot F, Ducrocq L: Potential role of tryptophan derivatives in stress responses characterized by the generation of reactive oxygen and nitrogen speies. J Pineal Res, 2008, 45, 235-246.

34. Picinato M, Haber EP, Carpinelli AR, Cipolla-Neto J: Daily rhythm of glucose-induced insulin secretion by isolated islets from intact and pinealectomized rat. J Pineal Res, 2002, 33, 172-177.

35. Pugazhenthi K, Kapor M, Clarkson AM, Hall I, Appleton I: Melatonin accelerates the process of wound repair in full-thickness incisional wounds. J Pineal Res, 2008, 44, 387-396.

36. Raikhlin NT, Kvetnoy IM, Kadagidze ZG, Sokolov AV: Immunomorphological studies on synthesis of melatonin in enterochromaffine cells. Acta Histochem Cytochem, 1979, 11, 75-77.

37. Reiter RJ, Korkmaz A, Paredes SD, Manchester LC, Tan DX: Melatonin reduces oxidative/nitrosative stress due to drugs, toxins metals and herbicides. Neuro Endocrinol Lett, 2008, 29, 609-613.

38. Reiter RJ, Paredes SD, Korkmaz A, Joum J, Tan DX: Melatonin combats molecular terrorism at the mitochondrial level. Interdisc Toxicol, 2008, 1, 137-148.

39. Reiter RJ, Tan DX, Kim SF, Manchester LC, Qi W, Garcia JJ, Cabrera JC et al.: Augmentation of indices of oxidative damage in life-long melatonin-deficient rats. Mech Aging Dev, 1999, 110, 157-173.

40. Reiter RJ, Tan DX, Manchester LC, Pilar-Terron M, Flores LJ, Koppisepi S: Medical implications of melatonin: receptor-mediated and receptor-independent actions. Adv Med Sci, 2007, 52, 11-28.

41. Rodriguez C, Mayo JC, Sainz RM, Antolin I, Martin V, Reiter RJ: Regulation of antioxidative enzymes; a significant role for melatonin. J Pineal Res, 2004, 36, 1-9.

42. Sahna E, Parlakpinar H, Vardi N, Cigremis Y, Acet A: Efficacy of melatonin as protectant against oxidative stress and structural changes in liver tissue in pinealectomized rats. Acta Histochem, 2004, 106, 331-335.

43. Stumpf I, Bazwinsky I, Peschke E: Modulation of the cGMP signaling pathway by melatonin in pancreatic $\beta$-cells. J Pineal Res, 2009, 46, 140-147.

44. Stumpf I, Muhlbauer E, Peschke E: Involvement of the cGMP pathway in mediating the insulin-inhibitory effect of melatonin in pancreatic-cells. J Pineal Res, 2008, 45, 318-327.

45. Subramanian P, Mirunalini S, Pandi-Perumal SR, Trakht I, Cardinali DP: Melatonin treatment improves the antioxidant status and decreases lipid content in brain and liver of rats. Eur J Pharmacol, 2007, 571, 116-119.

46. Szablocs A, Reiter RJ, Letoha T, Hegyi P, Papai G, Varga I, Jarmay K et al.: Effect of melatonin on the severity of L-arginine-induced experimental pancreatitis in the rats. World J Gastroenterol, 2006, 12, 251-258.

47. Tan DX, Manchester LC, Terran MP, Flores LJ, Reiter RJ: One molecule, many derivatives: a never-ending interaction of melatonin with the reactive oxygen and nitrogen species. J Pineal Res, 2007, 42, 28-42. 
48. Terry PD, Villinger F Bubenik GA, Sitaraman SV: Melatonin and ulcerative colitis. Inflamm Bowel Dis, 2009, $15,134-140$.

49. Thor PJ, Krolczyk G, Gil K, Zurowski D, Nowak L: Melatonin and serotonin effects on gastrointestinal motility. J Physiol Pharmacol , 2007, 58, Suppl 6, 97-103.

50. Qi W, Tan RX, Reiter RJ, Kim SJ, Manchester LC, Cabrera J, Sainz RM et al.: Melatonin reduces lipid peroxidation and tissue edema in caerulein-induced acute pancreatitis in the rats. Dig Dis Sci, 1999, 44, 2257-2262.

51. Viswanathan M, Laitinen JT, Saavendra JM: Expression of melatonin receptors in arteries involved in thermoregulation. Proc Natl Acad Sci USA, 1990, 87, 6200-6203.

52. Weelky LB: Pharmacological studies on the mechanism of melatonin-induced vasorelaxation in rat aorta. J Pineal Res, 1995, 19, 133-138.
53. Wereszczynska-Siemiatkowska U, Mroczko B, Siemiatkowski A, Szmitkowski M, Borawska M, Kosel J: The importance of interleukin 18, glutatione peroxidase and elenium concentration changes in acute pancreatitis. Dig Dis Sci, 2004, 49, 642-650.

54. Zawilska JB, Skene DJ, Arendt J: Physiology and pharmacology of melatonin in relation to biological rhythms Pharmacol Rep, 2009, 61, 383-410.

Received:

November 20, 2009; in revised from: March 9, 2010. 